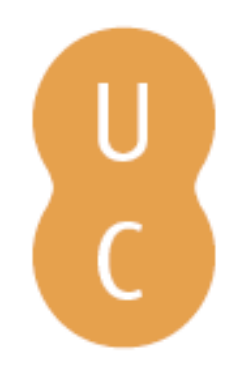

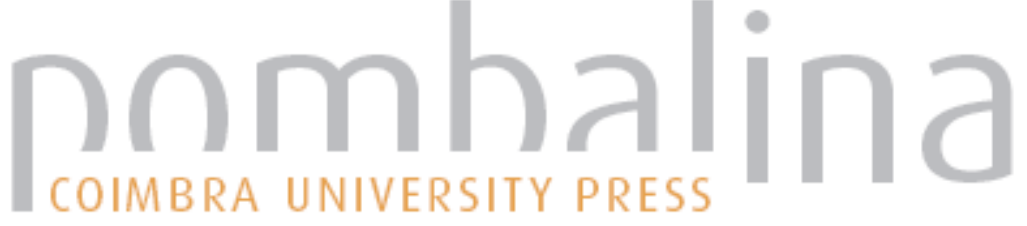

\section{Ciência: um peão redondo num mundo quadrado}
Autor(es):
Kroto, Harold
Publicado por: Imprensa da Universidade de Coimbra; Gradiva
URL
persistente:
URI:http://hdl.handle.net/10316.2/32650
DOI:
DOl:http://dx.doi.org/10.14195/978-989-26-0389-6_1

Accessed : $\quad$ 26-Apr-2023 06:50:16

A navegação consulta e descarregamento dos títulos inseridos nas Bibliotecas Digitais UC Digitalis, UC Pombalina e UC Impactum, pressupõem a aceitação plena e sem reservas dos Termos e Condições de Uso destas Bibliotecas Digitais, disponíveis em https://digitalis.uc.pt/pt-pt/termos.

Conforme exposto nos referidos Termos e Condições de Uso, o descarregamento de títulos de acesso restrito requer uma licença válida de autorização devendo o utilizador aceder ao(s) documento(s) a partir de um endereço de IP da instituição detentora da supramencionada licença.

Ao utilizador é apenas permitido o descarregamento para uso pessoal, pelo que o emprego do(s) título(s) descarregado(s) para outro fim, designadamente comercial, carece de autorização do respetivo autor ou editor da obra.

Na medida em que todas as obras da UC Digitalis se encontram protegidas pelo Código do Direito de Autor e Direitos Conexos e demais legislação aplicável, toda a cópia, parcial ou total, deste documento, nos casos em que é legalmente admitida, deverá conter ou fazer-se acompanhar por este aviso.

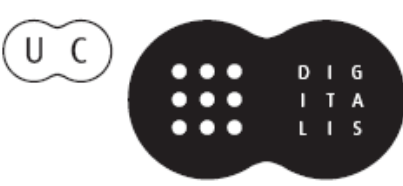


C I E N C I A I B E R T A

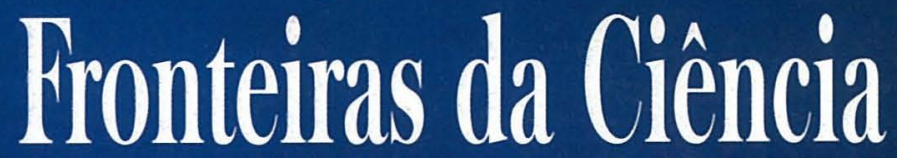

Desenvolvimentos Recentes - Desafios Futuros

RUI FAUSTO • CARLOS FIOLHAIS • JOÃO FILPE QUURRÓ

Coordenadores

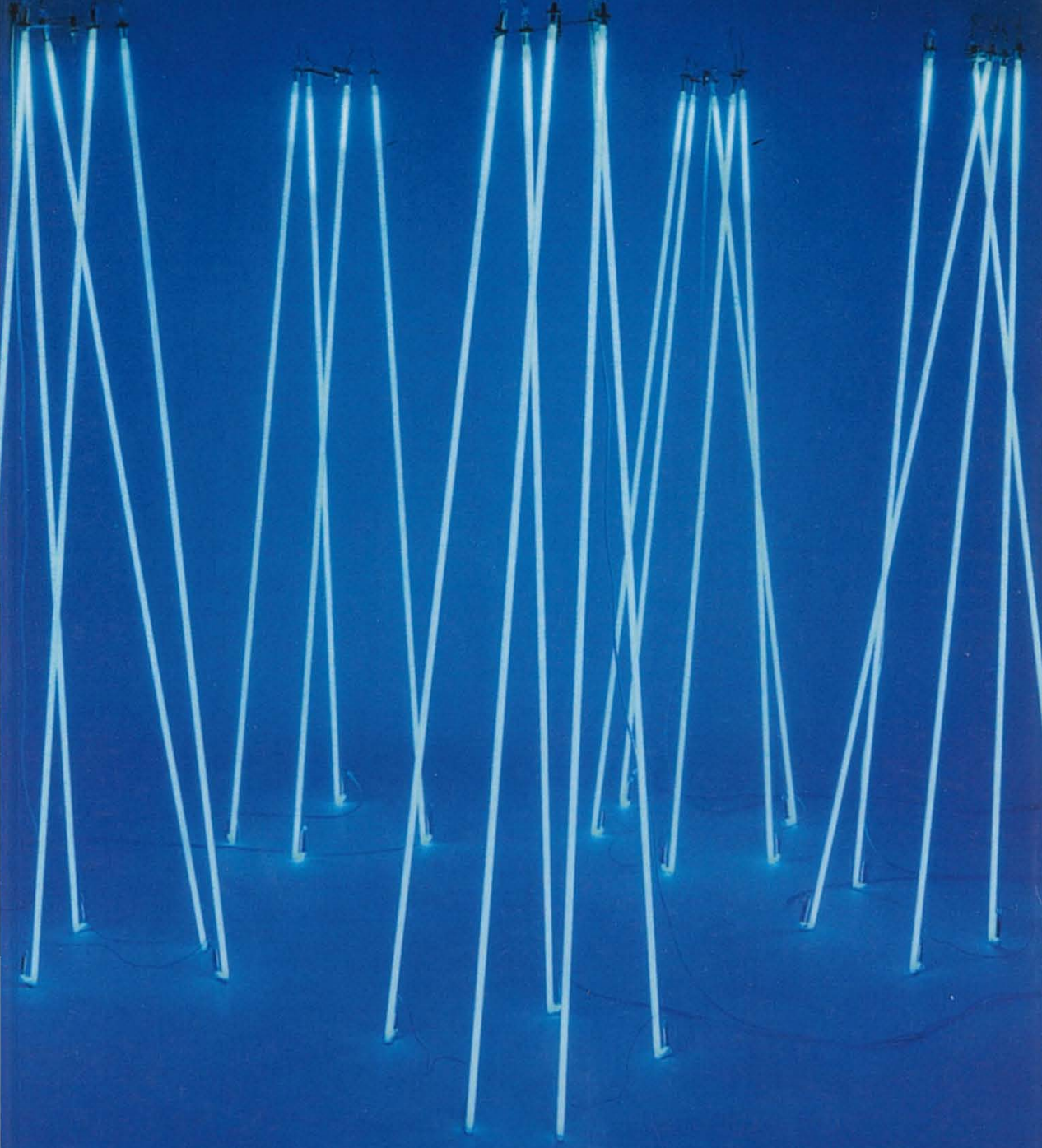

gradiva - Imprensa da Universidade de Coimbra 
(Página deixada propositadamente em branco) 


\section{RUI FAUSTO, CARLOS FIOLHAIS JOÃO FILIPE QUEIRÓ \\ Coordenadores}
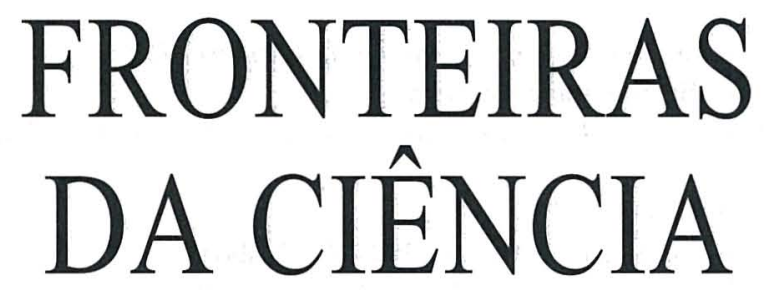

Desenvolvimentos Recentes Desafios Futuros 
(C) Gradiva - Publicações, L. da / Imprensa da Universidade de Coimbra, 2003 Coordenação editorial: Rui Fausto, Carlos Fiolhais e João Filipe Queiró Tradução: Jean Burrows, Vivien Burrows, Rui Fausto, Carlos Fiolhais e João Filipe Queiró

Revisão do texto: Isabel Pedrome

Capa: António Barros [Imprensa da Universidade. Coimbra], sobre imagem de «Águas Vivas», escultura de Silvestre Pestana, 2001

Foto: António Alves; Infografia: ESTÍMULUS [design]; Cortesia: Galeria Alvarez-Arte Contemporânea

Paginação: António Resende e Paula Isabel Jorge

Impressão e acabamento: G.C. - Gráfica de Coimbra, L. ${ }^{d a}$

Reservados os direitos para Portugal por:

Gradiva - Publicações, L. ${ }^{\text {da }}$ e Imprensa da Universidade de Coimbra

Gradiva - Publicações, L.da

Rua Almeida e Sousa, 21, r/c, esq.•1399-041 Lisboa

Telefs. $213974067 / 8 \cdot 213971357 \cdot 213953470$

Fax $213953471 \cdot$ Email: gradiva@ip.pt

URL: http://www.gradiva.pt

Imprensa da Universidade de Coimbra

Rua Antero de Quental, 195 • 3000-033 Coimbra

Telefs. 351239853110

Fax 3512398531 19・e-mail: fjrpress@ci.uc.pt

URL: http://www.imp.uc.pt

ISBN: 972-662-923-3

1." edição: Agosto de 2003

Depósito legal n. ${ }^{\circ} 199$ 463/2003 
Harold Kroto

School of Chemistry,

Universidade de Sussex

Reino Unido

\section{Ciência: um peão redondo num mundo quadrado}

Vou começar por falar sobre ciência e sobre o significado que ela tem, não só para mim, como também para muitas outras pessoas.

\section{Padrões e Simetrias}

$\mathrm{Na}$ figura 1 vemos alguns filtros de formas. Gostaria de saber quantos dos presentes brincaram com brinquedos iguais a estes quando eram crianças... Verifico que muitos tiveram um brinquedo desses. E quantos de vocês ofereceram este brinquedo aos vossos filhos?

Bem, uma mãe, cujo nome não importa, ofereceu este brinquedo ao seu filho. A criança pegou no cubo e tentou fazê-lo passar através do orifício redondo. Tanto o forçou que ele acabou por passar. Então pegou na peça triangular e também a forçou a passar pelo mesmo orifício. Nessa altura, a mãe começou a ficar um pouco preocupada e decidiu levar o filho ao psiquiatra. Depois de breve diálogo, o psiquiatra disse: Hum, parece que realmente esta criança usa a mesma solução para todos os problemas... Só há, de facto, uma profissão adequada para ele. Eu sugiro que ele vá para a política... senhora Clinton.

Contudo, estas formas e estruturas simétricas são realmente bastante interessantes. Consideremos, por exemplo, estes utensílios de pedra 
descobertos na Escócia; parecem ter sido esculpidos há dois ou três mil anos e foram encontrados no local onde decorreu o primeiro desafio de futebol entre o Glasgow Rangers e o Celtic. Naqueles tempos os espectadores eram muito mais cultos; esculpiam as rochas em belas formas simétricas antes de as arremessarem aos adeptos da equipa adversária. É claro que este gosto pela simetria está profundamente enraizado em nós. Nos trabalhos de Piero della Francesca ou de Leonardo da Vinci, por exemplo, observamos com frequência o aparecimento da figura de um icosaedro truncado - de facto, esta figura tem o mesmo padrão que uma bola de futebol.
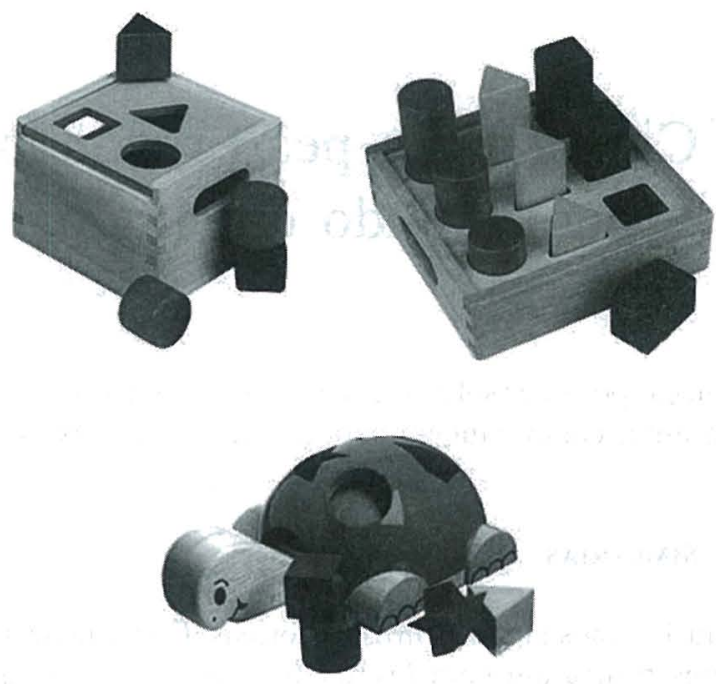

Fig. 1 - Filtros de formas. Brinquedos como estes despertam o interesse do ser humano pelas formas geométricas desde a mais tenra idade

Concluímos então que este tipo de estruturas simétricas parece ter um significado especial. Os padrões de simetria de alguma maneira impressionam profundamente os nossos sentidos. Consideremos uma passagem do "primeiro livro de Química», o Timeu, de Platão. Espero que todos se apercebam de que este foi realmente o primeiro livro de química. Eu não me apercebi até bem tarde de que este foi o único livro 
de química decente que algum dia foi escrito. Por exemplo, neste livro, Platão afirma o seguinte: Em primeiro lugar, é claro para toda a gente (!) que o fogo, a terra, a água e o ar são corpos, e todos estes corpos são sólidos, e todos estes sólidos são limitados por superficies, e todas as superficies planas são compostas por triângulos [...] Desta maneira, Platão descobriu a tabela periódica grega. Esta tinha cinco elementos - mais um do que a senhora Thatcher alguma vez parece ter conhecido, a julgar pelo financiamento que concedeu à Química no Reino Unido quando esteve no poder. De qualquer modo, esta afirmação de Platão foi muito poderosa e os ecos do seu poder podem ser escutados no seguinte parágrafo de um importante artigo de Van Vleck. Nele se diz que praticamente toda a gente sabe que as componentes do momento angular total de uma molécula segundo os eixos $x$, y e $z$, fixos no espaço, satisfazem relações de comutação descritas por expressões do tipo

$$
J_{x} J_{y}-J_{y} J_{x}=i \hbar J_{z}
$$

Ainda ontem, ao passear na rua Ferreira Borges, fui perguntando aos transeuntes que ia encontrando se conheciam tal facto e, acreditem ou não, nem uma única pessoa sabia o que quer que fosse sobre o assunto! Bem, eu confesso que em Brighton também ninguém sabe nada disto!

De qualquer maneira, pareceu-me que faria bem em aprender esta matéria, visto que Van Vleck afirmava que toda a gente a conhecia. Então, cheguei à página 60 do livro de Condon e Shortely Teoria dos Espectros Atómicos. Este livro não só é um excelente livro, mas é também um livro impresso de forma extraordinariamente elegante, e a página 60 é uma das suas páginas mais bonitas - e talvez uma das mais importantes. As equações aí contidas traduzem o elegante tratamento matemático de Dirac da interacção da radiação com a matéria (espero que todos consigam compreender a dedução até ao fim do dia de hoje, de forma a perceberem as relações estabelecidas por Dirac). E na página 60 apresenta os detalhes da dedução das regras de selecção que estabelecem a forma como a luz e a matéria interagem e, deste modo, determinam coisas como a cor dos materiais, etc. Penso que esta página é não só muito bela do ponto de vista científico, mas também do ponto de vista estético - o tipo de letra utilizado é também elegante e eficaz. Só é preciso algum tempo para compreender a dedução!

Se nos familiarizarmos com a teoria quântica do momento angular - o que temos de fazer se quisermos perceber de espectroscopia chegamos a uma relação que estabelece que existem $2 J+1$ componentes do momento angular. Quase toda a química surge deste resultado, isto 
é, quando $J$ é $0,2 J+1=1$; quando $J$ é 1 , o número de componentes é $2 J+1=3$; para $J=2,2 J+1=5$, e por aí adiante; deste modo surge a estrutura da tabela periódica de Mendeleev. Basicamente, racionalizamos o facto de que a primeira linha de tabela possui $2 \times 1$ elementos, a segunda $2 \times(1+3)$, a terceira $2 \times(1+3+5)$, etc.

Pode assim verificar-se que as simetrias matemáticas traduzem características fundamentais das leis que governam a natureza. Esta afirmação resume a primeira parte do que eu queria dizer; a segunda parte é que o apreço por estes padrões abstractos se encontra profundamente enraizado no consciente humano.

\section{Os Cientistas na Sociedade}

Um problema crucial com o qual a ciência se confronta hoje em dia é que a ciência fundamental é cara e os governos tentam continuamente controlar a forma como ela se desenvolve. Deixem-me dizer alguma coisa sobre os químicos. Na verdade, vou fazê-lo apresentando uma citação que retirei de um artigo de John Cornforth (extraído da lição que apresentou à Sociedade de Química Australiana por ocasião do seu $75 .^{\circ}$ aniversário). Este é um dos artigos mais maravilhosos que alguma vez li. John é, de facto, um cientista extraordinário e um grande humanista, que partilhou o Prémio Nobel com Prelog, em 1975. Vive actualmente em Sussex e é um bom amigo.

Os químicos que criaram novas formas de matéria transformaram de um modo ainda mais proeminente o mundo moderno: novos metais, plásticos, compostos, etc. A lista é muito extensa e os químicos criaram os materiais para tudo isto. Para os físicos, matemáticos, biólogos e para aqueles que se dedicam às ciências da Terra podem contar-se histórias semelhantes. Os cientistas estão envolvidos na génese da sociedade moderna e a maior parte deles dedica a sua carreira a responder a solicitações do estado ou do mercado. São tão úteis à sociedade que a grande maioria dos cidadãos, constituida por não cientistas, considera ser para isso que eles existem. Cada vez mais a maioria insiste que os cientistas se devem concentrar sobretudo naquilo que a sociedade diz que precisa deles, e, tal como os professores de ciências nas escolas e universidades, a sua actividade deve consistir em treinar pessoas que continuarão a satisfazer essas necessidades e desejos.

Steacie foi um grande cientista canadiano. Foi o arquitecto principal do National Research Council of Canada (NRCC) entre 1950 e $1970-$ os anos dourados dessa importante instituição. Se lerem a colectânea dos 
seus discursos, que foi publicada pela editora da Universidade de Toronto, poderão encontrar muitas observações que soam como acordes consonantes com o nosso mundo actual. Não consigo fazer justiça aqui às suas muitas ideias e pensamentos, mas gostaria de salientar uma, referida por Babbitt, que editou o livro: (Isto) torna perfeitamente claro que ele foi um oponente implacável a qualquer tentativa de formulação de um plano geral e alargado para a ciência. Acrescento eu: É impossível!...

Podem dizer aos políticos e a outros cidadãos importantes que a ciência está a ser destruída que eles não acreditarão - principalmente quando começarem a fazer ouvidos moucos. Suspeito também que muitos cientistas fazem ciência sem uma ideia muito clara da forma como realmente a fazem. Os governos legislam sobre matérias científicas e são muitas vezes ajudados por cientistas eminentes que pensam que sabem como as leis deveriam ser feitas - e eu suspeito que não sabem, principalmente porque acredito que existem muitas maneiras diferentes de fazer ciência e que uma estratégia geral pode resultar bem para um tipo de cientista e para a sua ciência, mas pode ser desastrosa para outro.

Comissões criadas com a finalidade de aconselhar sobre matérias de âmbito muito geral têm um valor relativamente pequeno, quando comparadas com comissões de peritos criadas para dar conselhos relativos à resolução de um problema particular [...]

No livro de Steacie, Babbit menciona também um outro grande cientista, Michael Polanyi, a propósito da relação dos cientistas com a sociedade: [...] como Polanyi, ele [Steacie] acredita na conjugação espontânea de iniciativas independentes e no exercício dos mecanismos informais que têm sido usados tradicionalmente pelos académicos: as reuniões cientificas e as comissões de peritos.

E eu transcrevo aqui uma afirmação de outro cientista famoso de nome Polanyi, o filho de Michael Polanyi, John Polanyi:

[...] Tal como no caso do mercado livre de bens e produtos, o empreendedor individual é quem está em melhor posição para julgar quais são as melhores oportunidades. Isto é assim porque o cientista, no seu dia-a-dia, é quem realmente conhece melhor as áreas de desenvolvimento mais promissoras no domínio de investigação que cultiva. Além disso, é ele quem mais interesse tem em aproveitar cuidadosamente o seu tempo, visto que será ele (ou ela) a ser punido no caso de ter feito uma má escolha do seu tema de investigação.

Tal é com certeza verdadeiro, a menos que se seja capaz de disfarçar o fracasso no relatório de investigação, salientando um resultado ocasional de maior sucesso. A minha perspectiva sobre este assunto é fortemente 
condicionada pelas grandes dificuldades que senti ao realizar a minha investigação. Uma vez referi a um colega no NRCC (Takeshi Oka, que era já nessa altura um investigador excelente - actualmente é professor na Universidade de Chicago): Só cerca de uma em dez das minhas experiências parece funcionar. Lembrar-me-ei para sempre da sua resposta: É uma boa percentagem, Harry!

Cá estamos nós então a jogar um jogo que temos de terminar na posse de um projecto de investigação bem sucedido, quando na realidade a experiência pode não ter funcionado, ou pode ter evoluído numa direcção completamente diferente, e nós temos de afirmar perante membros de uma comissão qualquer que ela correu bem e no sentido que originalmente havíamos previsto. É um pouco complicado fazer isto se o verdadeiro sucesso foi de $10 \%$, mas é isto, de facto, que acontece muitas vezes. Em boa verdade, eu creio que a melhor investigação envolve quase sempre problemas e projectos de investigação que correm mal, no sentido em que se obtêm resultados totalmente inesperados!

No seu livro $O$ Futuro do Capitalismo, Theroux dá aos governantes um conselho sobre estratégia: O papel correcto dos governos nas sociedades capitalistas, numa era de grande importância do trabalho intelectual, é representar os interesses do futuro no presente. Contudo, os governos actuais estão a fazer precisamente o contrário. Estão a diminuir o investimento no futuro para aumentar o consumo no presente.

\section{CiênCIA FUndamental}

A ciência fundamental, ou básica, é o grande problema da ciência em Portugal, tal como na Grã-Bretanha. Recentemente no Reino Unido foi lançado um plano geral para a ciência - precisamente aquilo a que Steacie resistiu com tanta firmeza e eu considero não ser possível concretizar. Pudemos ouvir afirmações como esta: Eu suspeitaria de um cientista que não fosse capaz de, antes de mais, explicar os motivos por que faz o seu trabalho.

Bem, tal suspeita aplica-se com toda a certeza a mim próprio, visto que não tive ideia nenhuma de que: $a$ ) o meu trabalho no princípio dos anos 70 (com John Nixon) viria a resultar num campo totalmente novo da química do fósforo, hoje em dia florescente; $b$ ) os meus trabalhos laboratoriais (com David Walton) sobre cadeias longas de átomos de carbono (inicialmente levado a cabo por razões bastante esotéricas do âmbito da dinâmica quântica que me pareciam fascinantes) culminariam num programa de investigação em radioastronomia (com Takeshi Oka, 
Lorne Avery, John McLeod e Norm Broten, no NRCC) que revelou uma perspectiva totalmente nova sobre a composição molecular do meio interestelar, e que $c$ ) uma ideiazinha pessoal para simular as condições numa estrela de carbono gigante vermelha resultaria na fantástica descoberta da molécula de $\mathrm{C}_{60}$, buckminsterfulereno (com Jim Heath, Yuan Liu, Bob Curl e Rick Smalley).

A propósito do mesmo assunto, um industrial, membro do painel de utentes da Engineering and Physical Sciences Research Council (EPSRC), engasgou-se quando decidiu falar sobre a investigação pura: Sinto-me desconfortável com a ideia da investigação pura e do brilhantismo que muitas vezes se lhe associa porque ela implica uma actividade com pouco sentido de orientação.

Bem, há alguns meses eu estava em Napa Valley, a norte de São Francisco, nos Estados Unidos, e vi um velho Volvo acidentado, abandonado num parqueamento automóvel, que tinha, por cima do pára-choques, uma inscrição com uma frase espantosa, que resume os meus sentimentos sobre todos os assuntos culturais e sobre a ciência em particular. Era uma citação da Song of Aragorn, de J. R. R. Tolkien:

Nem todos aqueles que se perdem estão perdidos...

Quando reflecti sobre isto pensei que era muito bom estar em São Francisco e aqueles sujeitos estarem noutro lugar qualquer.

Podemos perguntar: o que é a ciência fundamental? No artigo de John Cornforth é descrito de forma eloquente um exemplo famoso que serve de arquétipo - um daqueles exemplos que tocam toda a gente.

Aqui está um caso muito típico, verdadeiro. Algumas pessoas decidiram examinar os efeitos de um campo eléctrico sobre células vivas. Criaram um campo eléctrico entre duas superfícies de platina e imergiram-nas num líquido de cultura. As células morreram, mas as pessoas que fizeram a experiência eram verdadeiros cientistas e resistiram a extrair a conclusão óbvia, tendo verificado que as células não estavam a ser mortas pelo campo eléctrico mas a ser envenenadas por quantidades residuais de platina que se dissolvera. Relataram as suas descobertas a um colega que investigou e comprovou um efeito pronunciado sobre células cancerígenas. Em resultado de uma pesquisa numa biblioteca de quimica para encontrar um composto solúvel de platina encontrou-se uma substância que tinha sido produzida há cem anos por um químico de outro país cujos interesses eram apenas a química dos compostos de platina. [Como sabem, não existe muita química da platina - é o que se aprende nos livros; a platina é um elemento bastante inerte, sendo por isso bastante difícil trabalhar com ela. O seu preço é também muito elevado. Mas aquele cientista tinha 
achado uma boa porção dela!] Este composto mostrou ser ainda mais eficiente no combate às células cancerígenas do que inicialmente parecia. Um grande número de pessoas que hoje estão vivas estariam já mortas não fora a curiosidade construtiva, mas não pré-orientada, de vários cientistas, separados pelas disciplinas que praticavam, pela nacionalidade e pelo tempo. Os factores que se combinaram nesta história de sucesso foram a curiosidade, o cepticismo e a boa comunicação. [Isto significa que não se devem esconder os resultados que se obtêm. Devem publicar-se. Em especial, não se devem ocultar os resultados aos nossos competidores!] Conjuntamente, estes três factores produziram um resultado que ninguém previra ou esperara, $e$ isto é a essência da investigação. No entanto, tem sido sempre dificil persuadir aqueles que financiam a investigação cientifica de que os resultados previsiveis não têm grande valor e de que a melhor solução consiste em empregar uma equipa de cientistas que seja capaz de estabelecer as ligações fundamentais entre os resultados dos outros $e$, por vezes, os seus próprios resultados.

Gostaria agora de vos falar um pouco sobre a descoberta do $\mathrm{C}_{60}$, o buckminsterfulereno. Tratou-se de investigação pura, mais escura do que brilhante, se tivermos em conta a escuridão da investigação espacial. Nos anos 70, em Sussex, juntamente com os meus colegas Anthony Alexander, Colin Kirby e David Walton, sintetizámos e estudámos certas moléculas formadas por cadeias longas de átomos de carbono. Mais tarde, em colaboração com Takeshi Oka, Lorne Avery, Norm Broten e John McLeod, no NRCC, em Otava, usámos um radiotelescópio para estudar as nuvens negras de poeira e gás que se encontram dispersas na nossa galáxia. Estas nuvens correspondem a regiões do céu muito escuras, onde apenas algumas estrelas são observáveis. Os gregos imaginavam que o céu era uma redoma de vidro observada do seu interior e que as estrelas eram diamantes presos à superfície interior da redoma. As regiões escuras onde não podiam ser observadas estrelas correspondiam a buracos na redoma - vidro esmagado por um membro da claque do Tottenham que tinha arremessado uma pedra contra ele - e através dos buracos era possível observar as profundezas do espaço. Hoje em dia, obviamente, sabemos mais sobre este assunto - foi um membro da claque do Arsenal! De forma mais séria, no entanto, quando olhamos para estas áreas escuras com um radiotelescópio encontramos moléculas formadas por uma cadeia de carbono em algumas nuvens, e tais moléculas são realmente muito interessantes e bastante abundantes. A pergunta Porque é que elas lá estão? é particularmente interessante. $\mathrm{O}$ meu ponto de vista sobre esta matéria, que difere do que é geralmente aceite, é que estas moléculas 
foram formadas na atmosfera de uma estrela de carbono, gigante vermelha, fria, que as terá ejectado para o espaço interestelar.

$\mathrm{Na}$ altura destas descobertas ficámos todos muito entusiasmados. A figura 2 mostra o grupo de investigação que realizou estas experiências. Eu gosto muito desta fotografia porque ela revela que houve um tempo em que eu tinha cabelo. Não tenho a certeza se o Lorne alguma vez chegou a tê-lo. Esta fotografia evidencia também a minha ligação com o NRCC. Foi um tempo fantástico para mim. Adorei o meu período de pós-doutoramento no Canadá e o tempo, nos anos 70, durante o qual trabalhámos no projecto das cadeias de carbono no espaço.

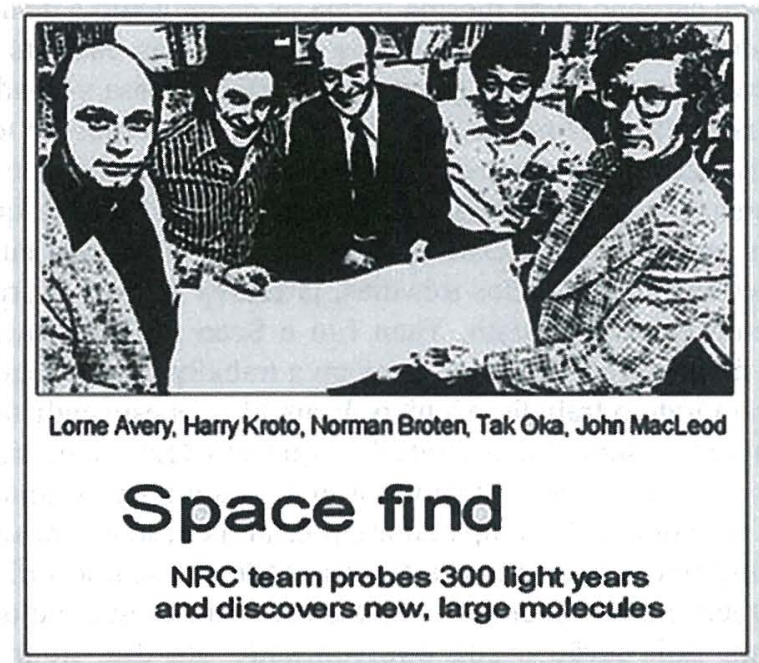

Fig. 2 - A equipa de investigação do NRCC que realizou, nos anos 70, um programa de investigação em radioastronomia que revelou uma perspectiva totalmente nova sobre a composição molecular do meio interestelar

Afortunadamente, em 1984 visitei a Rice University a convite de um amigo, Bob Curl. À minha chegada ele disse-me que eu deveria visitar o laboratório de Rick Smalley, onde estava a ser desenvolvida uma técnica inovadora, extraordinariamente poderosa no estudo de agregados 
moleculares. Basicamente, um laser é focado sobre um disco feito de material refractário, como o alumínio ou o ferro, e, quando um pulso de hélio passa através de um canal de cerca de $1 \mathrm{~mm}$ no disco, o laser dispara, produzindo um plasma; quando o plasma arrefece, dá origem a agregados moleculares que são aspirados para uma câmara de vazio, de forma a possibilitar o seu estudo por espectrometria de massa. Olhando para este aparelho, comecei a interrogar-me sobre a possibilidade de ele produzir um plasma semelhante ao existente numa estrela de carbono se o disco metálico fosse substituído por um disco de carbono. Naquela tarde fiz esta sugestão a Bob Curl, que me disse que iria discutir a possibilidade de iniciarmos um trabalho de investigação nessa área com Rick Smalley.

As estrelas de carbono criaram todo o carbono existente no universo. Os átomos de carbono (e da mesma forma os de oxigénio e de azoto, etc.) de qualquer pessoa foram produzidos numa destas estrelas há muito tempo. Ficaram agora a saber quem é, de facto, a vossa verdadeira mãe!

Passados cerca de 17 meses, em Agosto de 1985, recebi um telefonema de Bob Curl dizendo-me que estavam prestes a iniciar a minha experiência e perguntando-me se eu queria ir a Houston ou se preferia que ele me enviasse os resultados. É escusado dizer que queria realizar eu próprio a minha experiência e, passados três dias, já estava no Texas. Travei então conhecimento com Jim Heath, Yuan Liu e Sean O'Brien, que eram os estudantes de pós-graduação que estavam a trabalhar com o equipamento e que fizeram todo o trabalho técnico. Eram eles os especialistas capazes de pôr em funcionamento o aparelho, que era tecnicamente bastante complexo. Graças a esta preciosa ajuda, dispus de tempo para me concentrar no monitor do computador e prestar atenção aos resultados que nele iam surgindo. Os estudantes fizeram todo o trabalho difícil e Bob, Rick e eu recebemos o prémio - mas os estudantes que me ouvem não desesperem, pois terão a sua oportunidade um dia: quando forem professores poderão pôr os estudantes a trabalhar para si.

No entanto, as novidades resultantes da experiência foram boas e más. As boas foram que começámos a demonstrar que as moléculas constituídas por cadeias de carbono se formavam nas condições do plasma induzido por laser, tal como eu esperava; as más notícias, que tínhamos detectado uma espécie química não esperada: um intruso. Na minha impressão dos resultados, escrevi a nota: $\left\langle\mathrm{C}_{60}{ }^{+}(\right.$?)». O que seria isto? Bem, para abreviar uma longa história, pensemos na grafite. A coisa mais importante de que nos lembramos sobre este material, que vem descrita em qualquer manual escolar, é a grafite consistir em camadas de folhas perfeitamente planas de átomos de carbono ligados uns aos outros de modo a formarem uma rede hexagonal. Naquela altura estava com Bob Curl, cujo gabinete de 
trabalho tem um chão de mosaicos hexagonais. Todas as manhãs eu me sentava... e contemplava aquele pavimento. Pensava no significado preciso da observação que tínhamos feito. Como poderia o número 60 relacionar-se com aquele chão? Então ocorreu-me algo que vira durante uma visita ao Canadá em 1967. A figura 3 mostra a abóbada desenhada por Buckminster Fuller para o pavilhão dos Estados Unidos na Expo 67 em Monreal.

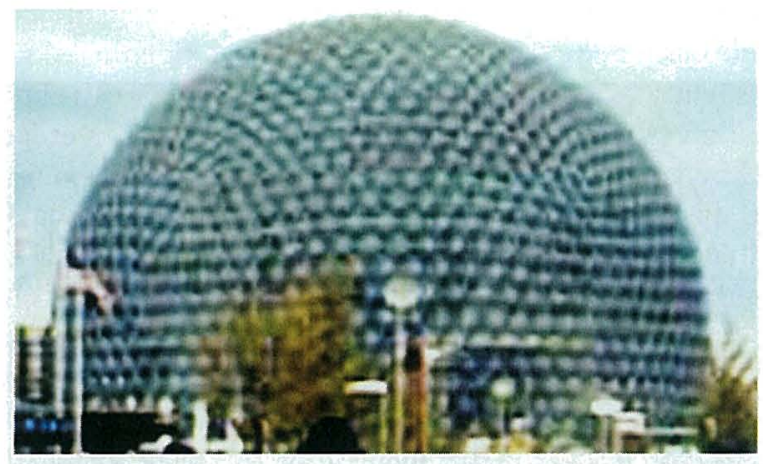

Fig. 3-A abóbada de Buckminster Fuller

Pode ser que Buckminster Fuller tenha observado um pavimento semelhante ao de Bob Curl e tenha pensado o modo de encurvar uma rede geométrica hexagonal de modo a formar uma cúpula arredondada. Buckminster Fuller, no entanto, descobriu o segredo dessa estrutura. Assim, também nós nos debruçámos sobre o modo de encurvar uma rede de grafite para formar uma bola. Lembrei-me então de outra coisa: um objecto que eu próprio tinha montado para os meus filhos vários anos atrás, um poliedro esferóide. Lembrei-me também de que esse objecto não era só formado por hexágonos, mas também possuía algumas faces pentagonais. Numa noite, em Setembro, Rick foi para casa tentar formar poliedros esferóides com hexágonos e lembrou-se deste objecto, que eu the tinha descrito uns dias antes, especialmente do facto de nele existirem algumas faces pentagonais. Só quando os pentágonos foram incluídos na 
estrutura esta se curvou e se fechou sobre si própria de modo a fazer surgir a fantástica estrutura que se apresenta na figura 4. Quando a vimos apercebemo-nos logo de que ela teria de estar correcta. A estrutura era tão bonita que não podia estar errada. Lembro-me de ter pensado que de qualquer forma, mesmo que a estrutura estivesse errada, não importava, pois toda a gente gostaria imediatamente dela! Sugeri então que déssemos à molécula o nome de buckminsterfulereno - um nome um pouco comprido e difícil de pronunciar, mas redondo e, além disso, com a terminação cientificamente correcta, -eno. Assim, decidimos intitular o artigo em que apresentámos a nossa descoberta $« \mathrm{C}_{60}$ : buckminsterfulereno».

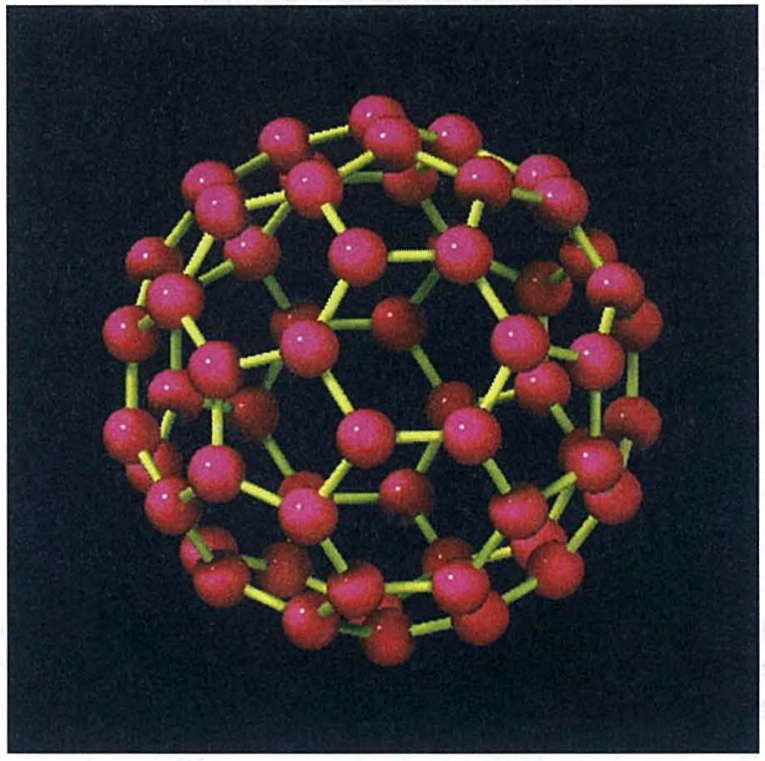

Fig. $4-C_{60}$, buckminsterfulereno

No início Rick Smalley não gostou do nome, talvez porque era muito longo, e no artigo sugerimos outras possibilidades. Para aqueles que não gostam do nome existe sempre uma alternativa - o nome correcto 
segundo a nomenclatura oficial da União Internacional de Química Pura e Aplicada (IUPAC):

Hentriacontaciclo [29. $29.0 \cdot 0^{2,14} \cdot 0^{3,12} \cdot 0^{4,59} \cdot 0^{5,10} \cdot 0^{6,58} \cdot 0^{7,55} \cdot 0^{8,53} \cdot 0^{9,21}$ $.0^{11,20} \cdot 0^{13,18} \cdot 0^{15,30} \cdot 0^{16,28} \cdot 0^{17,25} \cdot 0^{19,24} \cdot 0^{22,52} \cdot 0^{23,50} \cdot 0^{26,49} \cdot 0^{27,47} \cdot 0^{29,45} \cdot 0^{32,44}$ $\left..0^{33,60} 0^{34,57} \cdot 0^{35.43} \cdot 0^{36,56} \cdot 0^{37,41} \cdot 0^{38,54} \cdot 0^{39,51} \cdot 0^{40,48} \cdot 0^{42,46}\right]$ hexaconta 1,3 , $5(10), 6,8,11,13(18), 14,16,19,21,23,25,27,29(45), 30,32(44), 33$, 35(43), 36, 38(54), 39(51) 40(48), 41, 46, 49, 52, 55, 57, 59 - triacontaeno.

A figura 5 mostra a «equipa de futebol»: Bob Curl, o capitão de equipa, no meio, Rick Smalley e os dois estudantes de pós-graduação, Jim Heath e Sean O'Brien.

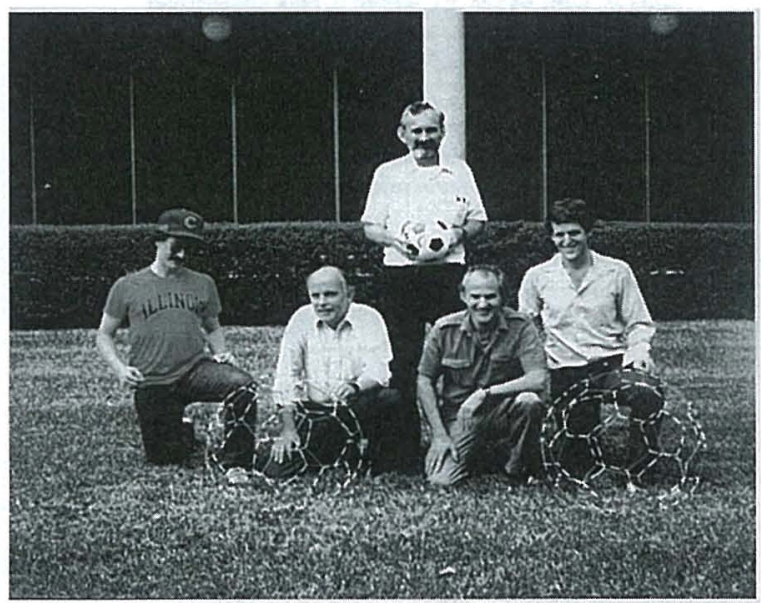

Fig. 5 - Os cientistas responsáveis pela descoberta do $C_{60}$, buckminsterfulereno. Da esquerda para a direita, Jim Heath, Rick Smalley, Bob Curl, Harry Kroto e Sean O'Brien

Verificou-se mais tarde que o $\mathrm{C}_{60}$ tinha uma pré-história. Existia um artigo muito imaginativo publicado em 1970 por Eiji Osawa que falava dessa espécie química. Espero que o vosso japonês seja suficiente para vos permitir ler o extracto apresentado na figura 6 do livro de Yoshida e Osawa. Aqui está a bola de futebol! 


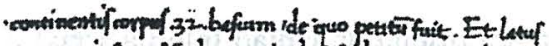

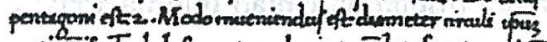

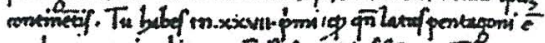

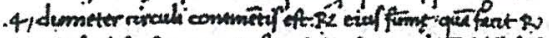

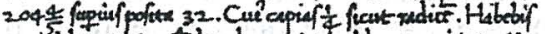

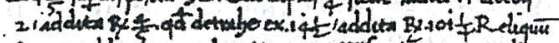

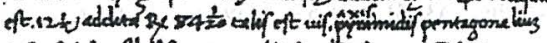

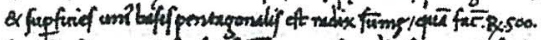

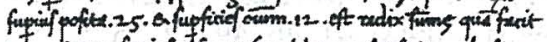

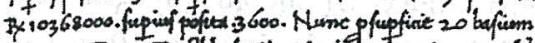

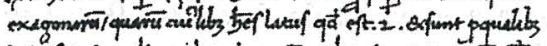

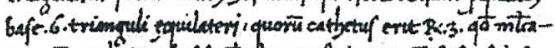

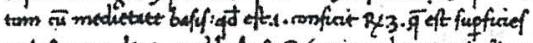

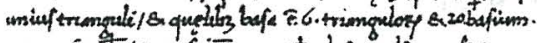

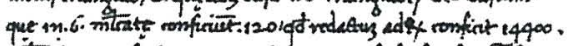

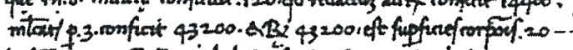

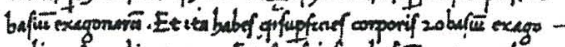

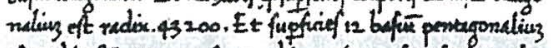

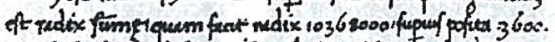
que of fupfiad minf romponif 32 bafuz. Nunc uidendu refate

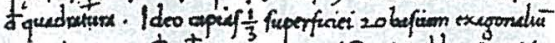

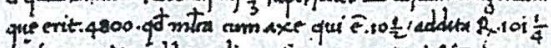

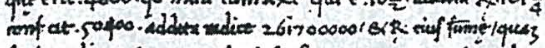

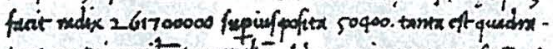

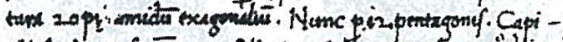

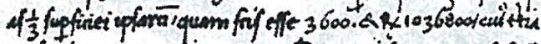

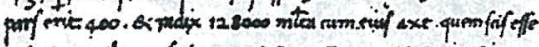

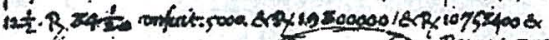

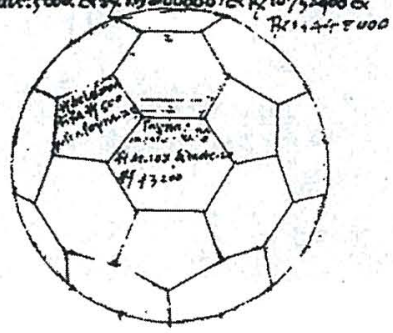

Fig. 6-Reprodução da página do artigo de Eiji Osawa publicado em 1970 onde se fazia referência à estrutura química que mais tarde viria a ser denominada

$C_{60}$, buckminsterfulereno

Para abreviar esta longa história, digamos que em 1985 sugerimos que o carbono podia formar uma gaiola fechada com a forma de uma bola de futebol feita com 12 pentágonos e 20 hexágonos. Então, em Sussex, a partir desse ano, tentámos vários modos de produzir o $\mathrm{C}_{60}$. Um dos que 
tentámos foi usando um arco de carbono - muito parecido com um dos antigos projectores que mostravam os filmes de Charlie Chaplin.

Numa segunda-feira, Jonathan Hare deixou um recipiente com uma solução vermelha em cima da minha secretária. Fiquei muito preocupado, perguntando-me se aquilo poderia estar certo - uma solução vermelha? Poderia aquilo ser o $\mathrm{C}_{60}$ ? Carbono solúvel! Tentámos efectuar uma análise da amostra por espectrometria de massa na quinta-feira, mas não conseguimos obter nenhum resultado. No dia seguinte recebi um telefonema da revista Nature... Recebemos muitas chamadas telefónicas ao longo da vida, mas nunca nos apercebemos da chegada de um furacão! Perguntaram-me se podia analisar um manuscrito sobre o $\mathrm{C}_{60}$ que tinha sido submetido para publicação e eu disse que sim. $O$ faxe chegou às 12.05 e foi uma bomba atómica! Era o manuscrito do extraordinário artigo de Wolfgang Krächmer, Lowell Lamb, Kostas Fostiropoulos e Don Huffman, certamente um dos mais notáveis do século XX - mas era péssimo para nós! Ao lê-lo verifiquei que eles também tinham uma solução vermelha. Interroguei-me: Devo suicidar-me ou... ir almoçar? Bem, qualquer pessoa que já tenha almoçado numa universidade inglesa sabe que não existe uma grande diferença entre estas duas atitudes. No entanto, naquele artigo também havia uma fotografia de cristais muito belos. Penso que esta é uma das fotografias científicas mais sublimes do século. Se alguém tivesse afirmado, antes de 1990, que era possível dissolver carbono puro em benzeno e recristalizá-lo, quase todos os químicos o considerariam louco. Bem, Krächmer, Lamb, Fostiropoulos e Huffman merecem o nosso reconhecimento e é pena que não tivessem podido partilhar o Prémio Nobel. Contudo, intelectualmente, eles partilharam-no.

O meu colega Roger Taylor descobriu então que é possível separar cromatograficamente a solução vermelha em duas outras soluções: uma magenta e outra também vermelha. Uma é uma solução de $\mathrm{C}_{60}$, a outra de $\mathrm{C}_{70}$. Pudémos também demonstrar conclusivamente a estrutura do $\mathrm{C}_{60}$, mostrando que o seu espectro de RMN (ressonância magnética nuclear) consiste numa única linha.

Hoje em dia é possível fazer química com este composto. Por exemplo, podemos ligar grupos fenilo em torno de um dos seu anéis pentagonais, formando uma molécula que parece ter cinco pés e se assemelha a uma criatura bacteriana capaz de andar. Podem analisar algumas das fantásticas criaturas moleculares que podemos criar a partir do $\mathrm{C}_{60}$ observando estes modelos moleculares. De facto, há uma variedade enorme de transformações químicas importantes que se podem realizar com o $\mathrm{C}_{60}$, de que não posso falar aqui por não se inserirem no âmbito desta conferência. 
Referirei apenas um aspecto: a figura 7 A) é a minha imagem da Guerra das Estrelas, uma estrela moribunda $\mathrm{C}_{60}$ perseguindo uma pequena nave espacial de ferroceno nos céus. Podemos agora criar estruturas nanocósmicas!

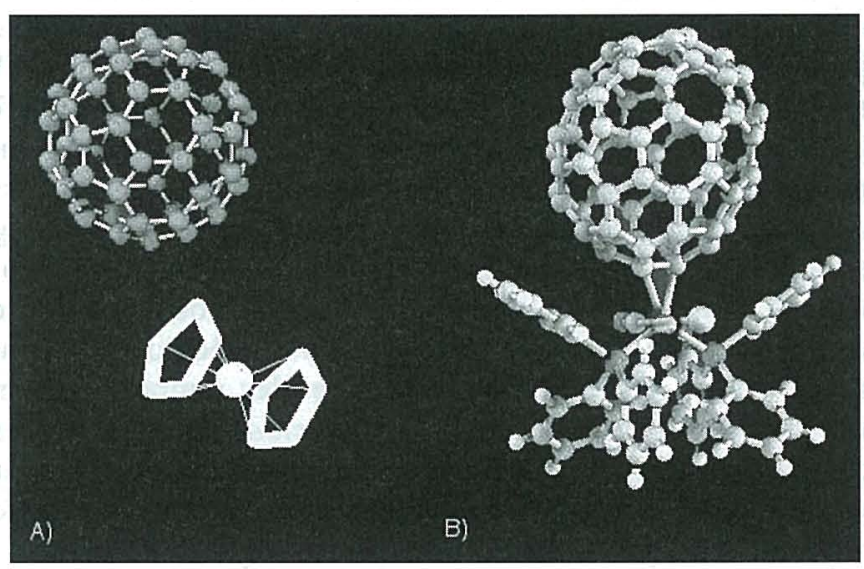

Fig. 7 - A) Modelos moleculares de $C_{60}$ e ferroceno; uma visão nanocósmica; $B$ ) exemplo de molécula derivada do $C_{60}$. Hoje em dia, muitas espécies químicas exóticas derivadas do $C_{60}$ foram já sintetizadas e estudadas, e o número destas moléculas continua a crescer!

De facto, o que tem vindo a entusiasmar muito as pessoas é a nanotecnologia que tem vindo a desenvolver-se a partir da descoberta do $\mathrm{C}_{60}$. Buckminster Fuller não só produziu abóbadas, mas também desenhou estruturas cilíndricas, que se encontram entre as suas arquitecturas patenteadas. Actualmente é possível produzir estruturas moleculares semelhantes feitas de carbono (figura 8). Estas estruturas são designadas por nanotubos. Uma estrutura destas é basicamente constituída por um tubo de grafite com dois semi-hemisférios de $\mathrm{C}_{60}$ nas suas bases.

Para se ter a percepção das dimensões destes materiais deve notar-se que a relação das escalas do $\mathrm{C}_{60}$ e de uma bola de futebol é aproximadamente a mesma que a de uma bola de futebol e do globo terrestre um factor de cerca de 100 milhões. Estas estruturas moleculares são 
qualquer coisa como cinquenta a cem vezes mais fortes que o aço e, apesar de serem cerca de seis vezes mais leves que o cobre, conduzem tão bem a electricidade como este metal. Deste modo, as possibilidades de utilização destes materiais no futuro, em áreas tão diversas como a engenharia civil ou a indústria de componentes electrónicos de escala nanométrica, são extremamente promissoras. Tal facto justifica o enorme número de projectos de investigação actualmente em curso que têm como objectivo a sua produção.

Quando fiz o primeiro modelo de uma destas estruturas, a que chamei zeppeleno, pelas suas semelhanças com um balão dirigível (Zeppelin), os
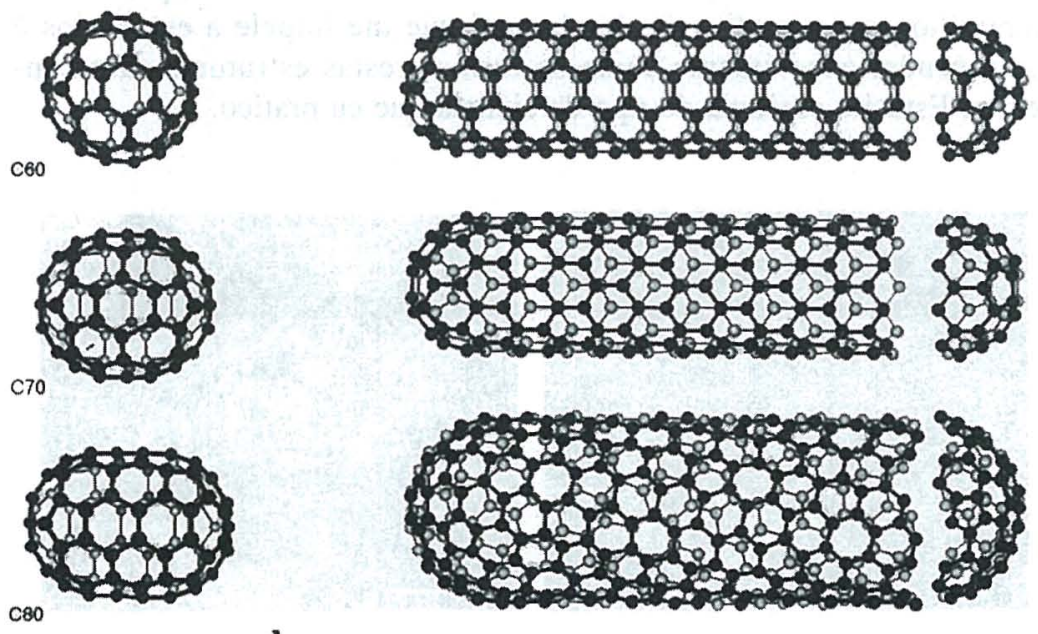

b

Fig. 8 - Nanotubos derivados do $C_{60}$ e das moléculas aparentadas $C_{70}$ e $C_{80}$

meus estudantes deram-lhe um nome bastante mais grosseiro. Tenho alguns estudantes fantásticos a trabalhar comigo que nunca fazem o que lhes digo - fazem sempre algo ligeira ou radicalmente diferente. São muito inventivos e imaginativos, o que me agrada bastante. O melhor que nos pode acontecer é termos estudantes que, quando se lhes diz que façam algo, procuram sempre qualquer coisa que ultrapasse a ideia original. Esta é uma das formas de proceder que podem facilmente conduzir a 
progressos científicos espantosos. Um dos avanços mais recentes conseguidos desta maneira é apresentado na figura 9. Podemos observar nesta figura algo que se assemelha à imagem de estrelas dispersas no firmamento. Contudo, se olharmos para tais objectos cada vez com maior pormenor, notaremos que estes são basicamente sementes de nanoestruturas semelhantes a flores, nas quais as «pétalas» brotam de um objecto central, e que existem centenas de estruturas destas. Neste momento não fazemos ideia do que estes objectos possam ser - estes resultados foram obtidos há apenas duas semanas, e não temos ainda qualquer ideia sobre o que está a acontecer -, mas uma coisa é certa: são realmente muito belos. Devo referir que não estou particularmente interessado em saber se eles são úteis ou não. São simplesmente maravilhosos e a motivação intelectual que me impele a estudá-los é compreender exactamente como se formam estas estruturas surpreendentes. Esta é a essência do tipo de ciência que eu pratico.
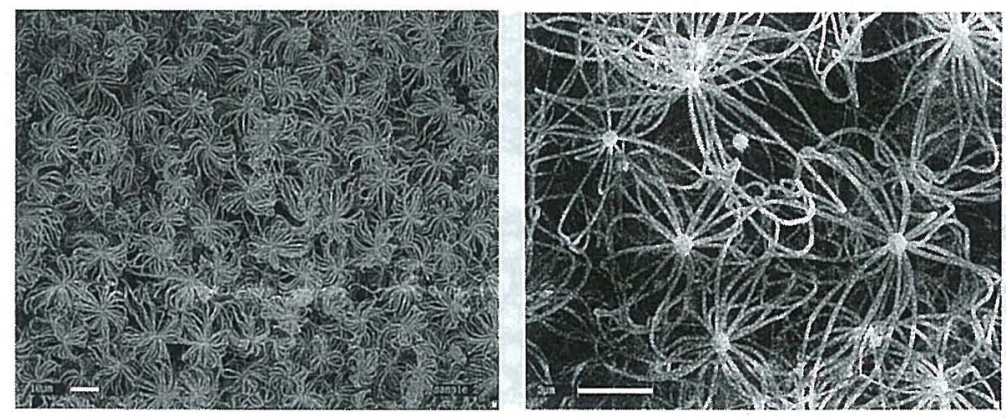

Fig. 9 - Nanoestruturas produzidas em Sussex e observadas a duas escalas diferentes

\section{A Compreensão Pública da CiênCia}

Quero ainda abordar outros assuntos que considero pertinentes, em especial os problemas associados às relações entre a ciência e a indústria, os media e os governos.

Relativamente aos media, a questão é ilustrada pela imagem apresentada na figura $10 a$ ), publicada num jornal há alguns anos, sob o título: Poderão os cientistas alterar a sua imagem de loucos? 


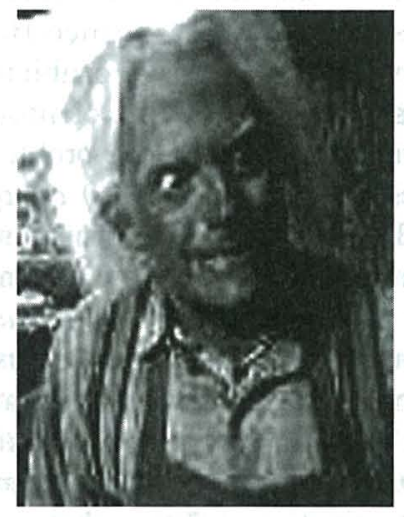

a)

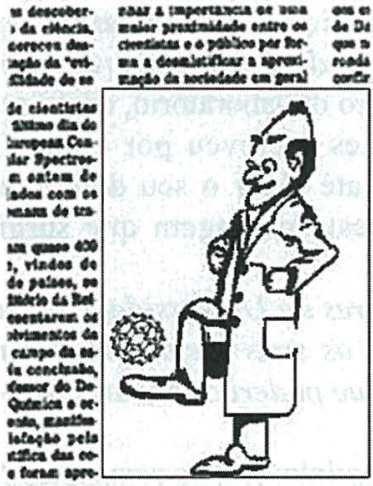

c)

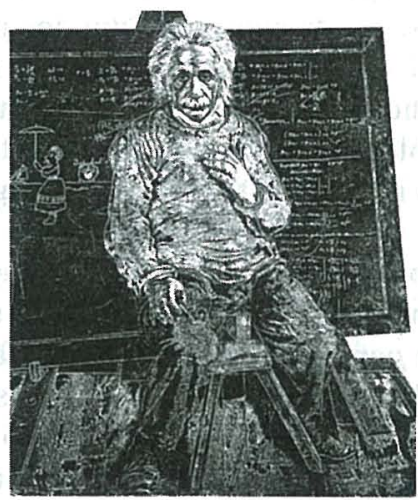

b)

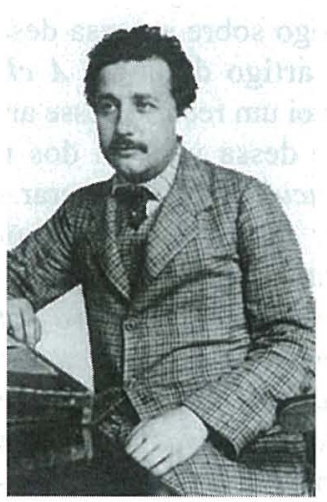

d)

Fig. $10-a$ ) imagem extraida do filme Regresso ao Futuro e publicada num jornal sob o título

«Poderão os cientistas alterar a sua imagem de loucos?»; b) Einstein, pintado por Hans Erni;

c) caricatura de Harry Kroto publicada num jornal por ocasião da descoberta do $C_{60}$;

d) a verdadeira imagem de Einstein na altura em que formulou as teorias da relatividade 
A propósito, eu cortei o cabelo especialmente para esta apresentação. A imagem apresentada na figura $10 \mathrm{~b}$ ) é um desenho que representa Einstein, da autoria de um dos meus artistas favoritos - o suíço Hans Erni -, e revela-nos quem é o responsável por este nosso problema. Tenho a certeza de que, se Einstein tivesse cortado o cabelo, os nossos problemas de imagem nunca se teriam tornado tão sérios. Este problema é evidenciado também na imagem apresentada na figura $10 \mathrm{c}$ ), que não é mais do que uma figura publicada num artigo de jornal onde eu próprio surjo como personagem principal. Coloquei este desenho num quadro no meu laboratório e alguém acrescentou logo: Estás muito bem parecido, Harry! Esta é de facto a imagem estereotipada do cientista.

Recentemente estive em Espanha, onde parece haver um maior respeito pelos cientistas, como se pode deduzir do facto de ter sido publicado num jornal de Cadiz um cartoon onde surjo a dançar flamenco com a supermodelo Naomi Campbell. Os cientistas não recebem este tratamento no Reino Unido ou, ao que julgo saber, em Portugal.

De qualquer modo, deixem-me mostrar-lhes um outro exemplo, desta vez extraído do jornal britânico Brighton Evening Argus. Foi publicado um artigo sobre a nossa descoberta de moléculas de carbono no espaço. Nesse artigo dizia-se: $A$ chave da vida pode estar entre as estrelas. Coloquei um recorte desse artigo num quadro do laboratório, como sempre faço, e dessa vez um dos meus estudantes escreveu por cima: Isto é espectacular! Fi-lo esperar mais um ano até obter o seu doutoramento por ter escrito aquilo. Agora reparem nesta passagem que surgiu no Brighton Evening Argus:

Uma descoberta nova feita por inventores da Universidade de Sussex poderá levar os cientistas a modificarem as suas ideias sobre o modo como a vida nasceu. A sua teoria afirma que poderão ter surgido formas de vida primitivas no espaço interestelar.

A melhor linha de texto, contudo, é a seguinte: [...] os compostos foram descobertos graças ao trabalho de cientistas canadianos no domínio da radioastrologia.

Mas ainda não terminei as minhas referências aos jornais. Simon Jenkins, num artigo de fundo do The Times, afirmava: [...] o currículo nacional dá uma ênfase despropositada à ciência e à matemática, de que poucos nós precisaremos.

Desejo que quando este senhor ligar o interruptor da luz esta nunca se acenda e ele mesmo tenha de o reparar. Desejo que, quando este senhor for a um hospital para realizar uma cirurgia cardíaca, esteja preparado para ser operado sem recurso a um anestésico - uma das maiores 
contribuições da química para o bem da humanidade. Pessoas como estas são perigosas porque perpetuam a filosofia de que é perfeitamente correcto não compreender o modo como o mundo moderno funciona ou não investir na educação da próxima geração de cientistas.

Uma compreensão básica dos aspectos fundamentais da ciência e da matemática não é assim tão difícil. Alguém na assistência julga ser capaz de resolver a equação desta figura? Aquilo para que quero chamar a atenção é que qualquer um pode resolver este problema quase sem pensar, pois esta é a equação que se tem de resolver para atravessar uma rua (figura 11) - até as galinhas conseguem!

Para dar um exemplo real do problema: John Maynard-Smith, um biólogo excelente, especialista em evolução e meu colega em Sussex, escreveu um artigo para uma revista e o editor disse-lhe que o texto não podia ter nenhuma equação. No entanto, John incluiu uma $d x / d t=a$, e disse que precisava mesmo dela. O editor, então, respondeu: Bom, está bem, eu deixo-o incluir esta equação, mas não seria possivel ao menos simplificá-la cortando os dês da fracção?

$\mathrm{E}$ o que se passa relativamente à relação entre a ciência e os governos? Consideremos, por exemplo, o caso do $\mathrm{C}_{60}$ e do governo britânico. $\mathrm{Na}$ Câmara dos Lordes foi colocada a seguinte questão: Que medidas tem o governo tomado para estimular o uso do buckminsterfulereno na ciência e na indústria?

A resposta a esta pergunta foi tão absurda que o melhor é apresentá-la aqui neste slide voltado do avesso. Faz muito mais sentido assim! Então Lorde Williams de Elvel perguntou: Meus senhores, estará o nobre senhor consciente, ao dar a sua resposta, de que esta molécula de carbono com a forma de uma bola de futebol é também conhecida, por um qualquer motivo extraordinário, por buckyball?

A baronesa Seare afirmou: Meus senhores, perdoem-me a ignorância, mas poderá o nobre senhor dizer se esta coisa é animal, vegetal ou mineral?

Meus senhores, fico satisfeito por a ilustre baronesa ter feito esta pergunta. Eu posso dizer que o buckminsterfulereno é uma molécula composta por 60 átomos de carbono, conhecida entre os químicos por $C_{60}$. Os átomos de carbono desta molécula formam uma gaiola composta por 12 pentágonos e 20 hexágonos que se encaixam como a superficie de uma bola de futebol.

$\mathrm{O}$ meu favorito foi Lorde Renton: Meus senhores, referem-se realmente a uma bola de futebol ou a uma bola de râguebi? 


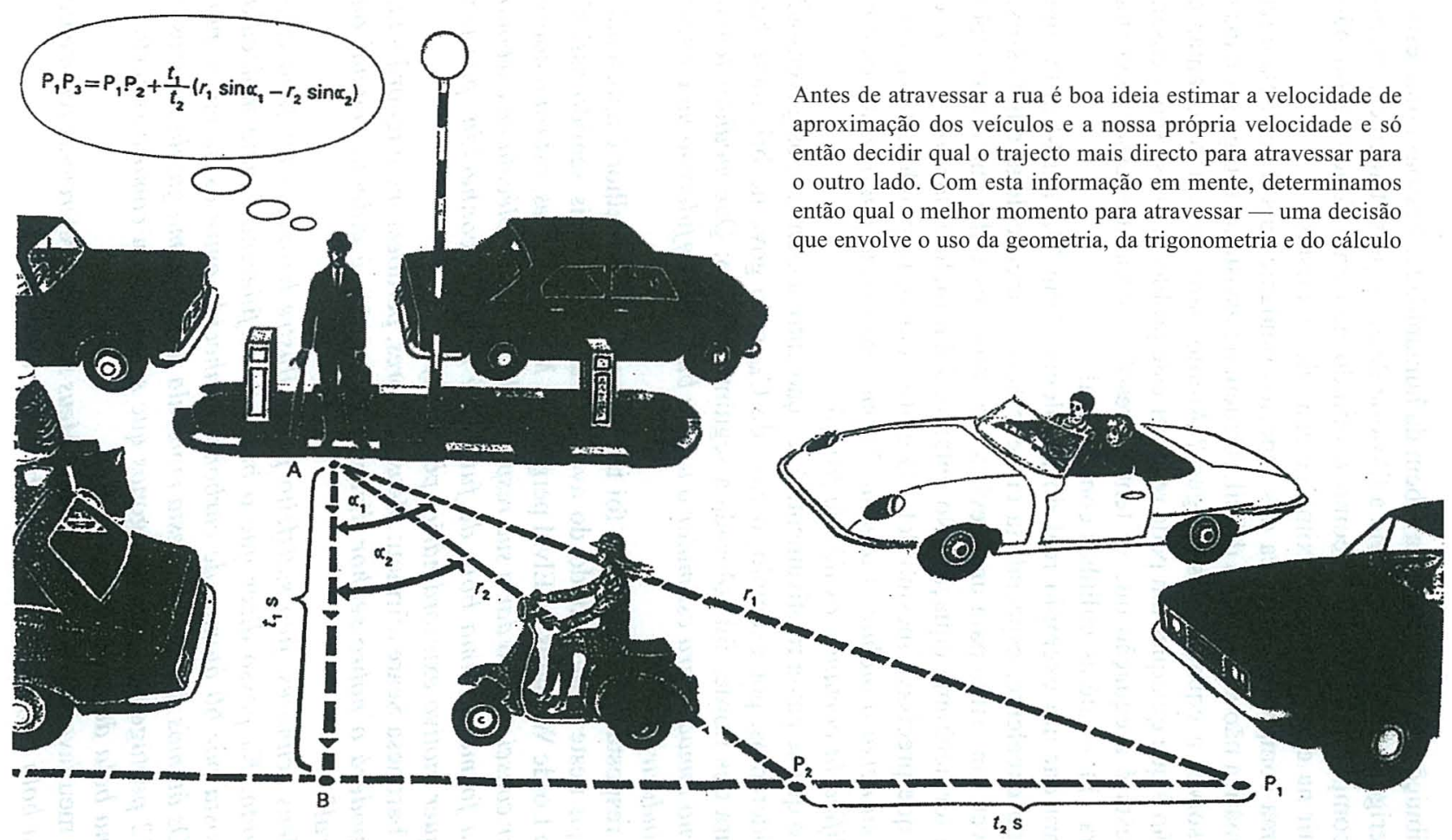

Fig. 11 - O simples acto de atravessar uma rua exige o dominio de alguns aspectos fundamentais elementares da ciência 
Felizmente existia alguém entre os assistentes, nas galerias destinadas aos visitantes, que sabia a resposta a esta pergunta! ${ }^{1}$

Então Lorde Campbell de Alloway perguntou: Meus senhores, para que serve esta molécula?

Lorde Reay respondeu prontamente: Meus senhores, supõe-se que possa ter várias utilizações: no fabrico de baterias, como lubrificante ou como semicondutor. No entanto, tudo isto não passa ainda de especulação. Poderá vir a demonstrar-se que não serve para nada.

Após o que Lorde Russel comentou: Meus senhores, poderemos então afirmar que, não servindo para nada, o faz muito bem?

Afinal veio a verificar-se que o buckminsterfulereno tem de facto uma utilidade, visto que um amigo meu descobriu o seguinte conjunto de pedidos publicado na coluna de anúncios pessoais da Harvard Gazete: Professor de Palm Beach procura senhora elegante para noites de teatro, e, um pouco mais abaixo, Fulerenos, fósseis e fungos; solteiros interessados nestes assuntos reúnem-se na base dos seus interesses cientificos!

\section{EduCaÇão Científica}

Nesta parte final vou referir-me a algumas questões relacionadas com a linguagem. Penso que os principais problemas da ciência se relacionam com a sua linguagem. Penso, por exemplo, que, se quisermos perceber realmente a cultura de um determinado país, é necessário aprendermos a língua que aí se fala, e isso requer algum esforço. Se algum japonês quiser compreender Shakespeare, terá de aprender inglês para poder apreciar os aspectos culturais essenciais subjacentes à sua obra.

Espero que a maior parte da assistência tenha aprendido a ler caracteres chineses. Basicamente, a inscrição em chinês apresentada na figura 12 é o equivalente, nesta língua, à conhecida expressão Cego, surdo e mudo! Em chinês diz-se: Se ouvires o demónio, afasta-te. Em japonês é Misaru, Kikasaru, Iwasaru, mas a expressão tem um duplo sentido muito interessante, visto que nesta língua saru também significa macaco. Para se entender este elegante sentido duplo é necessário aprender algum japonês. Em Nikko existe uma gravura magnífica dos três macacos, no

1 Neste ponto da sua exposição, Harry Kroto mostrou um slide com um chimpanzé a brincar com uma bola de futebol! (N. do T.) 
local onde foi enterrado o primeiro shogun - assim, embora o mesmo ditado possa ser encontrado em muitos locais diferentes e em muitas linguagens distintas, o seu significado preciso depende da forma como se expressa em cada uma das culturas onde se manifesta.
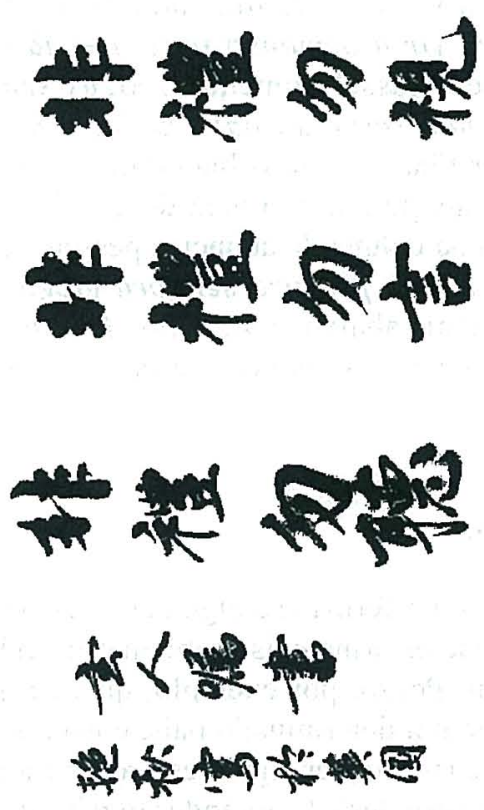

Fig. 12 - Escrito chinês tradicional equivalente a Cego, surdo e mudo!

Uma situação semelhante ocorre no mundo das ciências. Confrontado com a imagem da figura 13 , um químico imediatamente vê nela a molécula de benzeno. Se eu escrever simplesmente a fórmula $\mathrm{C}_{6} \mathrm{H}_{6}, 0$ mesmo cientista não hesitará em associá-la a esta magnífica arquitectura molecular, à história da sua compreensão e ao papel central que tem desempenhado na química.

Gostaria, por último, de vos falar sobre o meu envolvimento recente com a Vega Science Trust, uma empresa de produção de documentários científicos sobre a qual pode ser encontrada informação detalhada na Internet, em www.vega.org.uk. 
Nos últimos dois anos temos vindo a realizar programas para televisão que focam os aspectos culturais e intelectuais associados à ciência.

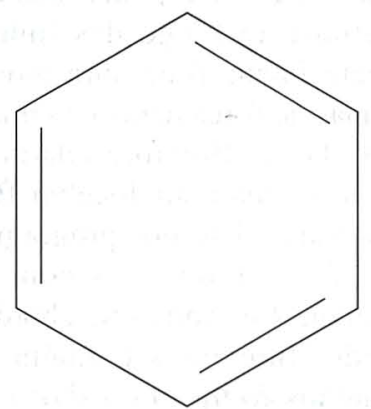

Figura 13 - Representação da molécula de benzeno, $\mathrm{C}_{6} \mathrm{H}_{6}$

Muitos dos programas científicos para televisão apresentam filmes de animais. Muitas vezes vemos filmes nos quais o arquétipo é uma águia que caça um gerbilo, o desfaz em pedaços e o enfia depois pelas goelas das pequenas aguiazinhas. É essencialmente isto e é certamente fascinante aprender em primeira mão, e com um colorido pormenorizado, a variedade de formas que a natureza inventou para se comer a si própria. Contudo, não considero que haja muita ciência nisto. Seria aliás relativamente fácil ter-se uma ideia sobre este assunto indo a um restaurante - não é preciso vê-lo na televisão. O que os programas da Vega procuram fazer é apresentar os aspectos culturais e intelectuais das diferentes áreas da ciência. Deste modo, espero que um dia uma grande parte das pessoas possa tornar-se verdadeiramente educada e consiga perceber a minha anedota sobre o editor que pediu ao meu colega cientista que simplificasse a equação diferencial eliminando os dês. De certa forma, não se trata de uma anedota; antes, é uma reflexão bastante triste sobre a circunstância de um dos avanços intelectuais mais importantes de todos os tempos, a invenção do cálculo (por Newton e Leibniz), ser apenas compreendida por um número reduzido de pessoas, apesar de muitas se considerarem a si próprias pessoas cultas. 
Dou-vos uma ideia do que temos vindo a fazer: gravámos, por exemplo, os programas A Química do Espaço, de autoria de Bill Klemperer, e $A$ Origem da Luz, de John Maynard-Smith. Akira Tonomura está actualmente a obter imagens de um campo de forças no interior de um magnete (sabe-se há muito que, se espalharmos limalha de ferro à volta de um íman, esta se alinha ao longo das linhas de força do campo magnético produzido pelo íman; Tonomura mostrou recentemente que podemos observar as linhas de força dentro do íman, usando um moderno microscópio electrónico). David Bomford fala-nos sobre Ciência e Arte; também gravámos um programa com Jocelyn Bell, que, com Anthony Hewish, descobriu os pulsares. Um dos programas mais recentes, e um dos mais importantes, foca as doenças com tempos de incubação prolongados. O apresentador, Roy Anderson, aborda a questão da epidemia de BSE no Reino Unido. Iniciámos também um novo conjunto de programas a que chamámos Reflexões sobre a Ciência. Estou muito orgulhoso desta série, em particular do episódio Como Estar Certo e Errado, de autoria de Sir John Cornforth, galardoado com o Prémio Nobel em 1975. John é surdo desde os vinte anos, mas o nosso programa captou o seu génio, o seu humanismo e a sua espantosa habilidade para comunicar de uma forma espirituosa e instrutiva. Nestes programas conseguimos uma excelente forma de falar sobre a ciência. Gravámos também Susan Greenfield, que descreve o seu trabalho sobre o cérebro. Estamos, pois, a fazer um grande esforço para levar a verdadeira ciência à televisão. Penso que isto tem de ser feito, pois de outra forma não conseguiremos resolver o problema do entendimento público da ciência. Pelo menos eu acredito nesta ideia.

No Japão, participei num workshop com miúdos de 8 e 9 anos e notei como eles gostavam de ciência. Bastava olhar para as suas caras. Pude tirar a mesma conclusão em Santa Barbara, noutro workshop com crianças de origem latina. Adoraram construir modelos do $\mathrm{C}_{60}$. Desta actividade partimos para a discussão de ciência a sério: a lei de Euler, $V+F-A=2$, que nos diz que o número de faces $(F)$ mais o número de vértices $(V)$ menos o número de arestas $(A)$ num sólido geométrico é sempre igual a 2. Depois disto, é possível manter facilmente um grupo de miúdos entretidos mais de meia hora a construir modelos de moléculas de carbono semelhantes ao buckminsterfulereno. Não existe um único professor que não considere que estas são as moléculas mais úteis que alguma vez foram feitas - por isso, têm necessariamente de ser boas! Além disto, pode observar-se a importância destas actividades no desenvolvimento da criatividade, olhando, por exemplo, para uma criança que descobriu que o $\mathrm{C}_{60}$ pode funcionar 
como um capacete! Ela julgava, certamente, que participava numa audição para um papel no filme $O$ Silêncio das Buckybolas!

A história que se segue foi tirada de uma banda desenhada que me foi oferecida por duas meninas da Angmering School, no Sussex:

Um miúdo novo na cidade:

- Olá, eu sou o diamante. Sou um tipo de carbono.

- Também eu. Eu sou a grafite. Nós somos os únicos tipos de carbono por aqui.

- Errado! Existe um novo tipo de carbono na cidade: o buckminsterfulereno, Bucky, para os amigos! Eu também sou um tipo de carbono, sabem?

- Não pode ser! Ele é redondo. Parece uma bola de futebol. Nós somos melhores do que ele.

- Mas... vocês podem fazer isto? - saltitou Bucky!

As crianças podem realmente ficar entusiasmadas com a química. Antes de terminar gostaria ainda de vos referir uma observação presciente e extremamente inteligente de John Cornforth apresentada à Sociedade Australiana de Química em 1985:

Mas os cientistas são uma pequena minoria, e as pessoas familiarizadas com a ciência, à parte os cientistas, são uma pequena minoria na administração, no governo e no mundo dos negócios na maioria dos países, incluindo este. O interesse dos políticos não vai, em geral, além das eleições seguintes. Aqueles que ainda não nasceram não votam e a maneira mais fácil de obter os votos da maioria das pessoas é prometer-lhes um aumento de poder de compra. A reacção do cidadão médio é pensar: O que é que a posteridade alguma vez fez por mim? $O$ administrador raramente tem uma preparação cientifica ou qualquer interesse em considerar um futuro a longo prazo. O homem de negócios quer obter o seu lucro o mais rapidamente possivel, para seu próprio usufruto e dos seus sócios. Todas estas pessoas parecem ter a mesma esperança vaga (se, de facto, chegam a pensar neste assunto) de que os cientistas encontrem uma maneira de salvar os gerações futuras do lixo para onde a geração actual as está a atirar.

A minha maior paixão é a arte - em particular as artes gráficas. Muitos dos livros que tenho em minha casa são livros de arte e quero aqui partilhar convosco esta página de uma das minhas mais recentes aquisições; penso que se trata de uma das observações mais humanas que alguma vez vi. O seu autor chama-se Stine:

Sou uma criatura alienígena. Fui enviado de outro planeta com uma saudação cordial do meu povo para vocês, povo da Terra: 
"Caros habitantes da Terra, quando vocês finalmente destruírem o vosso planeta e não tiverem um local para viver, podem vir viver connosco e nós ensinar-vos-emos a viver em paz e harmonia e dar-vos-emos também um cupão de desconto de $10 \%$ na compra de uma piza.»

Esta frase humanitária humorística resume bem o meu sentir. É um escrito maravilhoso e um comentário mordaz à vida moderna.

$\mathrm{Na}$ imagem que quero mostrar no final desta minha comunicação, um rapazinho, Ellis, ensina-nos que, se o $\mathrm{C}_{60}$ pode tornar uma criança tão exuberantemente alegre, necessariamente é uma coisa boa! 
(Página deixada propositadamente em branco) 
 \\ A palavra "fronteiras" pode ser tomada em} diferentes sentidos. Pode referir-se aos limites, necessariamente provisórios, entre o conhecido e o desconhecido, ou aos limites entre o possivel e o impossivel, e, dentro do possivel, entre o desejável e 0 indesejável. Fronteiras podem também ser as delimitações, nem sempre nítidas, entre ciência e não-ciência, e dentro da ciência, entre as várias disciplinas. Quais são então as fronteiras da ciência?

Neste livro, a resposta a esta pergunta é dada, segundo as mais diferentes perspectivas, por um conjunto notável de personalidades, cientistas ou não, entre as quais se contam três Prémios Nobel.

Rui Fausto, Carlos fiolhais e JoÃo Fillipe Queiró são, respectivamente, professores de Química, Física e Matemática na Faculdade de Ciências e Tecnologia da Universidade de Coimbra. 